\title{
EFFECT OF ROLLING ON THE FRACTIONAL RECRYSTALLIZATION BEHAVIOUR OF Al-Mg AND Al-Mg-Zr ALLOYS
}

\author{
M. S. Kaiser ${ }^{1 *}$, K. M. Shorowordi ${ }^{2}$ and H. M. Mamun Al Rashed ${ }^{2}$ \\ ${ }^{1}$ Directorate of Advisory, Extension and Research Services \\ ${ }^{2}$ Department of Materials and Metallurgical Engineering \\ Bangladesh University of Engineering \& Technology, Dhaka \\ ${ }^{*}$ Corresponding e-mail: mskaiser@iat.buet.ac.bd
}

\begin{abstract}
One set of Al-Mg and Al-Mg-Zr alloys are directly cold rolled and other set of those alloys are hot rolled and then cold rolled using a laboratory rolling mill. The effect of rolling on the fractional recrystallization of the alloys has been investigated using the micro-hardness variation. Isothermally annealed samples are also studied using JMAK type analysis to see if there exists any correlation between experimental and JMAK type analysis. From the microstructure, it is observed that the Al-Mg alloy becomes almost fully recrystallized state after annealing at $600^{\circ} \mathrm{K}$ for 60 minutes. The results also show that recrystallization fraction obtained by the two methods, shows the higher variation in zirconium added Al-Mg alloy as compared to the Al-Mg alloy. The fractional recrystallization of the cold rolled Al-Mg-Zr alloy is significantly lower than that of cold rolled Al-Mg alloy and hot and colled rolled Al-Mg-Zr, owing to the presence of fine $\mathrm{Al}_{3} \mathrm{Zr}$ precipitates. These metastable $\mathrm{LI}_{2}$ $\mathrm{Al}_{3} \mathrm{Zr}$ precipitates are thermally stable at high annealing temperatures.
\end{abstract}

Keywords: Al-Mg alloys, zirconium, annealing, recrystallization, JMAK analysis

\section{INTRODUCTION}

Aluminium-magnesium (Al-Mg) alloys are attractive for their high strength, high ductility, high formability, high corrosion resistnace and weldablity $[1,2]$. Various methods are applied to increase the strength and other properties by modifying the structures of Al-Mg alloys [3]. To achieve fine grain microstructure of Aluminum-magnesium alloys, controlling their microstructures during deformation processing is particularly important. Recrystallization during or immediately following hot deformation provides an opportunity for controlling grain size prior to cold deformation [4-6]. Microstructure can also be controlled by the method of minor alloying. It is found that addition of small amount of alloying elements such as $\mathrm{Zr}$, Ti and $\mathrm{Sc}$ increases the thermal stability of $\mathrm{Al}-\mathrm{Mg}$ alloys by the formation of dispersoids and also changes the crystallization behavior [7-9].

Strain hardening through extensive deformation is a popular method for achieving high strength of $\mathrm{Al}-\mathrm{Mg}$ alloys. High dislocation density is produced within the grains due to the application of cold rolling and increases the strength of the alloys. $\mathrm{Mg}$ and minor additions of other elements in $\mathrm{Al}$ influences the recrystalization behviour which control the garin size of the alloys. Since, at a crtical strain, recrystallization occurs by the formation of neucleation, the deformation beviour have important role in the grain finement. The recrystallization behavior of cold-rolled Al-alloys has been extensively studied in the literature [10-12]. The systemtic study on the recrystallization behavior of hot and cold rolled $\mathrm{Zr}$ added $\mathrm{Al}-\mathrm{Mg}$ alloy is very scarce.
The aim of the present work is to study the fractional recrystallization behavior of Al-Mg alloy and $\mathrm{Zr}$ added $\mathrm{Al}-\mathrm{Mg}$ alloy at different rolling conditions through the methods of micro-hardness variation.

\section{EXPERIMENTAL}

Two samples of Al-Mg and $0.3 \mathrm{Zr}$ containing Al-Mg alloys were fabricated through casting process. In the process of preparation of the alloys the commercially pure aluminium (99.9\% purity) was taken as the starting material. Melting was carried out in a resistance heating furnace under the suitable flux cover. First the aluminium was melted in a clay-graphite crucible, then magnesium lump (99.9\% purity) was added by dipping into the molten metal. Finally Al-Zr master alloy is added to second melt to obtain $\mathrm{Al}-\mathrm{Mg}-\mathrm{Zr}$ alloy. The final temperature of the melt was always maintained at $780 \pm 15^{\circ} \mathrm{C}$. Then the melt was allowed to be homogenised under stirring at $700^{\circ} \mathrm{C}$ and poured in a preheated steel mould $\left(200^{\circ} \mathrm{C}\right)$ size of $17 \times$ $150 \times 250$ in millimeter. Both the alloys were analysed by wet chemical analysis and spectrochemical method simultaneously to determine the chemical composition. The chemical compositions of the alloys are given in Table 1.

The cast samples were first machined to skin out the oxide layer from the surface and different samples were prepared from the castings. Some of the samples from both the alloys were kept in a resistance heating furnace at $400^{\circ} \mathrm{C}$ for 12 hours for homogenization. The homogenized samples were solutionized at $530^{\circ} \mathrm{C}$ for 2 hours and then quenched ice cooled salt water. Hot rolling of homogenized samples was carried out in a 
laboratory scale rolling mill of $10 \mathrm{HP}$ capacity at $400 \pm$ $5^{\circ} \mathrm{C}$. As-cast and hot-rolled samples of both the alloys were cold rolled using the same rolling mill upto the reduction of $80 \%$. Samples of $15 \times 15 \times 3 \mathrm{~mm}$ in size were prepared from the colled rolled sheet for the studying recrystallization kinetics. The samples were isothermally annealed at $600^{\circ} \mathrm{K}$ for different times ranging from 30 to 3600 seconds. Microhardness of the annealed samples was measured with a Micro Vickers Hardness Tester. The Knoof indentor was applied with $1 \mathrm{Kg}$ load for 10 seconds. At least seven indentation from different locations from each sample were taken. The recrystallization kinetics for the alloys in the present study is analyzed by assuming a JMAK type behavior for kinetics obtained from micro-hardness.

Microstructure of the samples were investigated by optica microscope (Versamet-II-Microscope) at different magnifications. For that samples were polished by standard metallographic technique and etched in a solution of Keller's reagent $\left(\mathrm{HNO}_{3}-2.5 \mathrm{cc}\right.$, $\mathrm{HCl}-1.5 \mathrm{cc}, \mathrm{HF}-1.0 \mathrm{ccand} \mathrm{H}_{2} \mathrm{O}-95.0 \mathrm{cc}$ ).

Table 1. Chemical Composition of the AL-Mg alloys (wt.\%)

\begin{tabular}{|c|c|c|c|c|c|c|c|}
\hline Alloy & $\mathbf{M g}$ & $\mathbf{Z r}$ & $\mathbf{S i}$ & $\mathbf{F e}$ & $\mathbf{S n}$ & $\mathbf{Z n}$ & $\mathbf{A l}$ \\
\hline 1 & 5.014 & 0.000 & 0.429 & 0.375 & 0.249 & 0.012 & Bal \\
\hline 2 & 5.124 & 0.304 & 0.507 & 0.269 & 0.238 & 0.012 & Bal \\
\hline
\end{tabular}

Sample designation:

Alloy 1-DC Directly Cold rolled Al-Mg alloy Alloy 2-DC Directly Cold rolled Al-Mg-Zr alloy Alloy 1-HC Hot and Cold rolled Al-Mg alloy Alloy 2-HC Hot and Cold rolled Al-Mg-Zr alloy

\section{RESULTS AND DISCUSSIONS Optical micrographs}

The microstructures of the ditectly cold rolled Al-Mg Alloy 1-DC, Al-Mg-Zr Alloy 2-DC, hot and cold rolled Al-Mg 1-HC and Al-Mg-Zr Alloy 2-HC are shown in Fig. 1. Al-Mg Alloy 1-DC shows coarse grains of the $\alpha$-Al dendrites and precipitates in the interdendritic regions. Fragmented and elongated dendrites along the direction of rolling, are also observed for both the alloys. But Zircomium added Al-Mg alloy 2-DC shows finer garin as compared to the Al-Mg alloy 1-DC. In case of Alloy 1-HC and Alloy 2-HC, the equiaxed grain structures (Fig. 1c and 1d) are revealed instead of dendritic structure which is found in direct colled rolled alloys._ It indicates due to hot and colled rolling, the dendritic structure has been transformed into equiaxed structure and the intermetallic compounds in the interdendritic regions are distributed throughout the structure. This is in agreement with some of the literatures concluding that even minor $\mathrm{Zr}$ addition has considerable effect on the microstructure refinement of aluminium alloys due to presence of Zr-bearing precipitates [13, 14].
If the alloys are annealed at $600^{\circ} \mathrm{K}$ for 1 hour, the Al-Mg Alloy 1-DC and Alloy 1-HC are seen to be recrystallised almost completely (Fig. 2a and 2c). However, the $\mathrm{Zr}$ added Alloy 2-DC and Alloy 2-HC are recrystallised partially at the same annealing condition (Fig. $2 \mathrm{~b}$ and $2 \mathrm{~d}$ ). From the detailed investigation of the microstructures, it is observed that the coarse secondary phase particles in the interdenritic regions are dissolved during homogenization at $600^{\circ} \mathrm{K}$ and a more homogeneous structure are obtained. In addition, the $\mathrm{Mg}_{2} \mathrm{Si}$ particles are dissolved partially and become more spherical in shape. The homogenization treatment also removes microsegregation between the secondary dendrite arms or within the grain [15]. The recrystallization of both the rolled base Al-Mg alloys are completed at about $600^{\circ} \mathrm{K}$. However, the recrystallization of $\mathrm{Zr}$ added alloys having fine precipitates of $\mathrm{Al}_{3} \mathrm{Zr}$ does not complete at the same temperature. These precipitates are coherent with the matrix. It is reported that recrystallisation is almost impossible in aluminum alloys when such particles are already present [16].

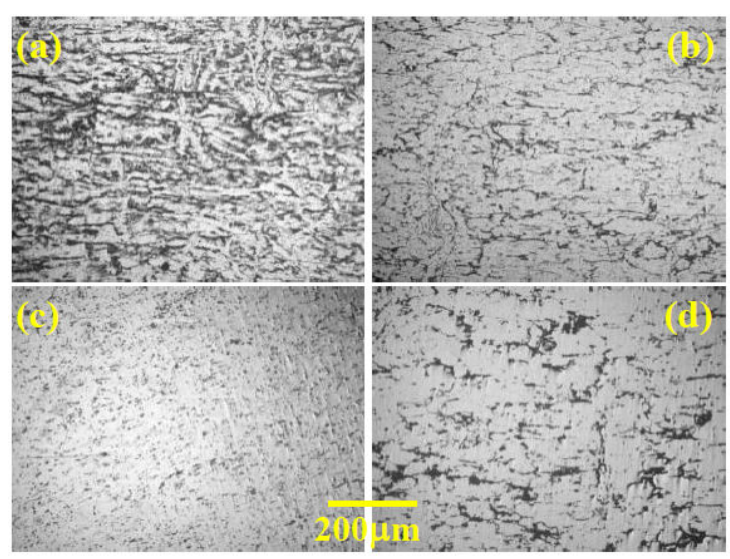

Figure 1. Optical micrograph of (a) Alloy 1-DC, (b) Alloy 2-DC, (c) Alloy 1-HC and (d) Alloy 2-HC.

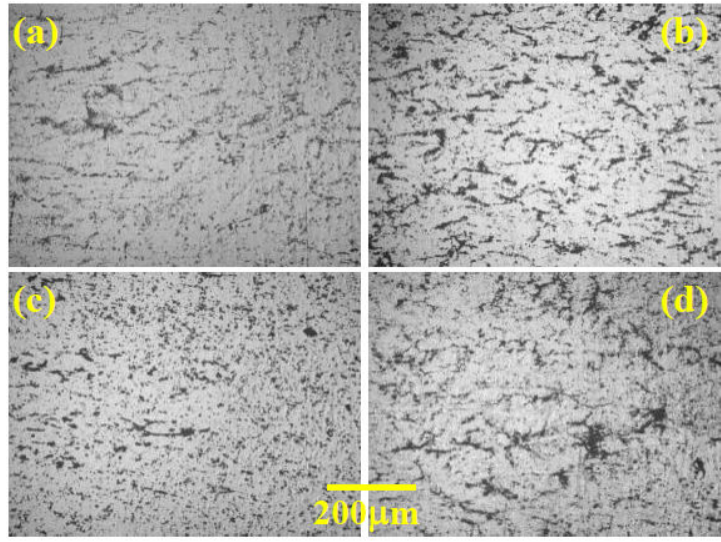

Figure 2. Optical micrograph of (a) Alloy 1-DC, (b) Alloy 2-DC, (c) Alloy 1-HC and (d) Alloy 2-HC annealed at $600^{\circ} \mathrm{K}$ for 1 hour. 


\section{Isothermal Annealing}

Fig. 3 shows the hardness variation with the isothermal annealing of ditectly cold rolled Alloy 1-DC, Alloy 2-DC, hot and cold rolled Alloy 1-HC and Alloy $2-\mathrm{HC}$ at $600^{\circ} \mathrm{K}$ for different time. It is observed that the rate and degree of initial softening is similar for Al-Mg Alloy 1-DC, Al-Mg-Zr Alloy 2-DC and Alloy 1-HC. Ternary Al-Mg-Zr Alloy 2-HC shows a very fast and steep decrease in hardness followed by a constant value. The initial softening of cold-worked alloys during isochronal ageing is thought to be due to rearrangement of dislocations at the annealing temperature. The trace element precipitates hinder dislocation movement and thus limit the softening. The major problem of $\mathrm{Al}-6 \mathrm{Mg}$ alloy which shows softening during use is overcome by zirconium addition. It is due to formation of $\mathrm{Al}_{3} \mathrm{Zr}$ hinders dislocation motion and reduces softening. Supersaturated Al-Zr solid-solutions decomposes into initially $\mathrm{Al}_{3} \mathrm{Zr}$ precipitates with a metastable cubic $\mathrm{L}_{2}$ structure, which finally transform to $\mathrm{Al}_{3} \mathrm{Zr}$ of equilibrium tetragonal $\mathrm{D}_{23}$ phase after prolonged aging at elevated temperatures $\left(>450{ }^{\circ} \mathrm{C}\right)$. The stability of the phases can be increased at high homologous temperatures by reducing a small lattice parameter mismatch between is $\mathrm{Al}_{3} \mathrm{Zr}$ and $\alpha-\mathrm{Al}$ [17, $18]$.

The initial drop in resistivity as shown in Figure 4 during isothermal annealing of the alloys for all conditions occurs due to dislocation rearrangement. The subsequent peak at higher annealing time for the zirconium added Alloy 1-DC is obviously due to the formation of fine $\mathrm{Al}_{3} \mathrm{Zr}$ particles. Hot and cold rolled Alloy 2-HC does not show such peak becase of the precipitation of $\mathrm{Al}_{3} \mathrm{Zr}$ already occurs during hot rolling. The final steady decrease in resistivity at higher annealing times stems from particle coarsening which reduces the number of scattering centres. Since precipitate coarsening is appreciable at high annealing temperature, the resistivity drop is noticeable [19].

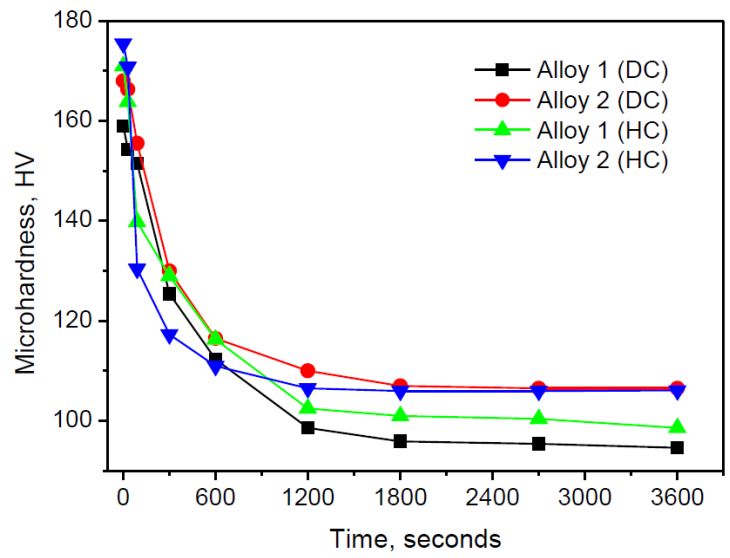

Figure 3. Variation of microhardness due to isothermal annealing at $600^{\circ} \mathrm{K}$.

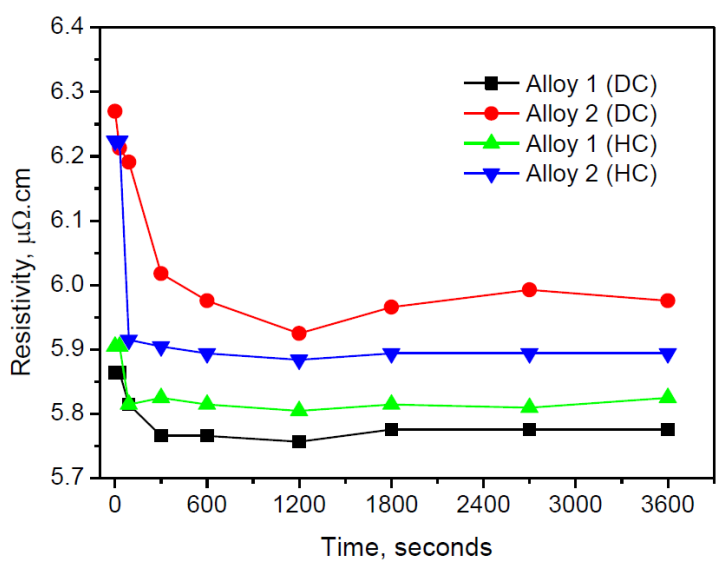

Figure 4. Variation of resistivity due to isothermal annealing at $600^{\circ} \mathrm{K}$.

\section{Recrystallization kinetics from microhardness variation}

The kinetics of recrystallization was determined from the microhardness values by considering the maximum and minimum values of microhardness, which are obtained from deformed and completely recrystallized samples respectively. The maximum and minimum values for microhardness of the alloys measured in the present study are given in Table 2 . The fraction recrystallized is obtained from the microhardness value by using the following formula [20]-

$X=\frac{H_{\max }-H_{i}}{H_{\max }-H_{\min }}$

Where $H_{\max }$ is maximum hardness corresponding to deformed sample (aging time, $\mathrm{t}=0$ ), $H_{\text {min }}$ is minimum hardness corresponding to fully recrystallized sample and $H_{i}$ is microhardness after a given annealing time [21]. Fully recrystallied sample got hold of the alloys annealed at $773^{\circ} \mathrm{K}$ for one hour. Fig 5 shows the variation of fraction recrystallized obtained from microhardness values for the samples annealed at $600^{\circ} \mathrm{K}$. The base Al-Mg alloys rolled at both the conditions (cold rolled Alloys 1 -DC and hot and cold rolled Alloys 1-HC) show the higher values of recrystallization as compered to the zirconium added alloys (Alloys 2-DC and Alloys 2-HC). This indicates that zirconium reduces the recrystllazation of $\mathrm{Al}-\mathrm{Mg}$ alloy at $\mathrm{DC}$ and $\mathrm{HC}$ rolling conditions. The $\mathrm{Al}_{3} \mathrm{Zr}$ precipitates formed in Al-Mg-Zr alloy favours to attain a large Zener drag which retards the movement of dislocation and subgrain boundaries. Thus the high resistance of recrystallization $\mathrm{Al}-\mathrm{Mg}-\mathrm{Zr}$ alloy as compared with Al-Mg alloy is suitable for the development of thermally stable Al-Mg alloys [22, 23]. 


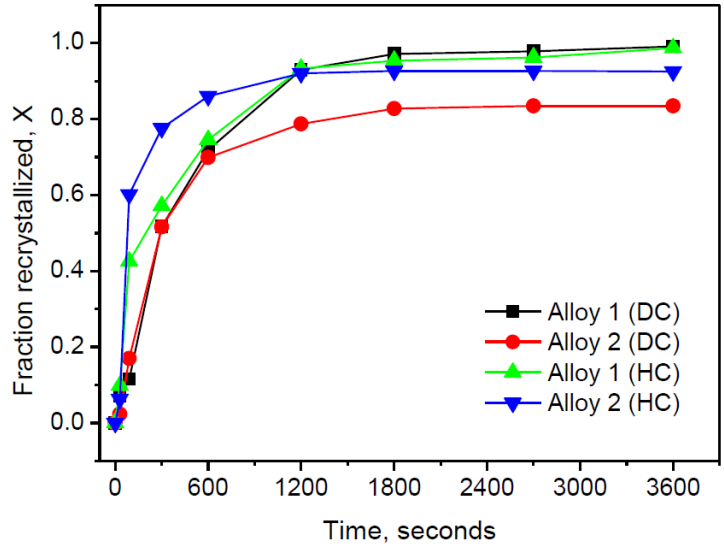

Figure 5. Recrystallization kinetics of the alloys obtained from microhardness data.

The kinetics of recrystallization can be represented in a mathematical form by using the JMAK relationship $[24,25]$. The variation of fraction recrystallized with annealing time in JMAK relationship is given as

$$
X=1-\exp \left[-(k t)^{n}\right]
$$

Here $\mathrm{n}$ and $\mathrm{k}$ are the JMAK exponent and temperature dependent constant, respectively. This equation can be rearranged to a linear relationship by using a logarithmic expression.

$$
\ln \left[\ln \left(\frac{1}{1-X}\right)\right]=n \ln (t)+n \ln (k)
$$

The slope of this linear expression will yield the exponent $n$ and the parameter $k$ can be obtained from the ordinate as shown in Fig. 6.

The values of the JMAK exponent $n$ and parameter $k$ can be used to obtain recrystallization kinetics of the alloys annealed at $600^{\circ} \mathrm{K}$ as shown in Fig. 7-10. All the alloys show the different slope for their different recrystallization behavior.

$X=1-\exp \left[-(0.001860 \times t)^{0.93276}\right]$ Alloy $1-\mathrm{DC}$

$X=1-\exp \left[-(0.001079 \times t)^{0.85728}\right]$ Alloy 2-DC

$X=1-\exp \left[-(0.002533 \times t)^{0.71713}\right]$ Alloy $1-\mathrm{HC}$

$X=1-\exp \left[-(0.002640 \times t)^{0.64662}\right]$ Alloy $1-\mathrm{HC}$

Table 2. Experimental value of maximum, minimum hardness and JMAK exponent of the alloys

\begin{tabular}{|c|c|c|c|c|}
\hline Alloy No. & $H_{\max }$ & $H_{\min }$ & $\mathrm{n}$ & $\mathrm{k}$ \\
\hline Alloy 1-DC & 159.0 & 94.0 & 0.93276 & 0.001860 \\
\hline Alloy 2-DC & 168.0 & 94.3 & 0.85728 & 0.001079 \\
\hline Alloy 1 -HC & 171.0 & 97.6 & 0.71713 & 0.002533 \\
\hline Alloy 2 -HC & 175.5 & 100.5 & 0.64662 & 0.002640 \\
\hline
\end{tabular}

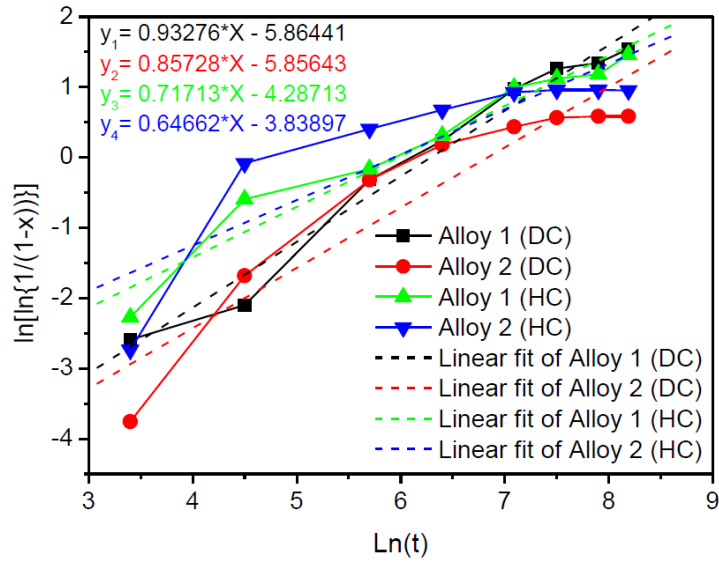

Figure 6. Plot of $\ln [\ln \{1 /(1-X)\}]$ Vs. $\ln (t)$, showing a linear relationship with a slope equal to the JMAK exponent.

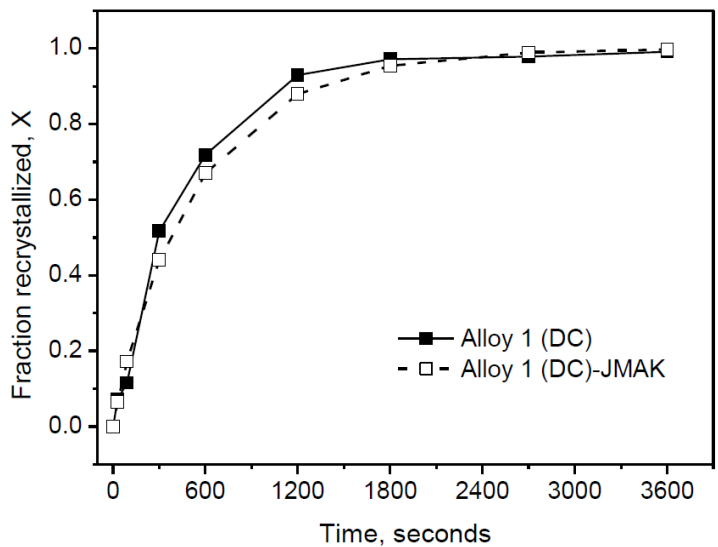

Figure 7. Recrystallization kinetics for the Alloy 1-DC from Micro-hardness data and JMAK analysis.

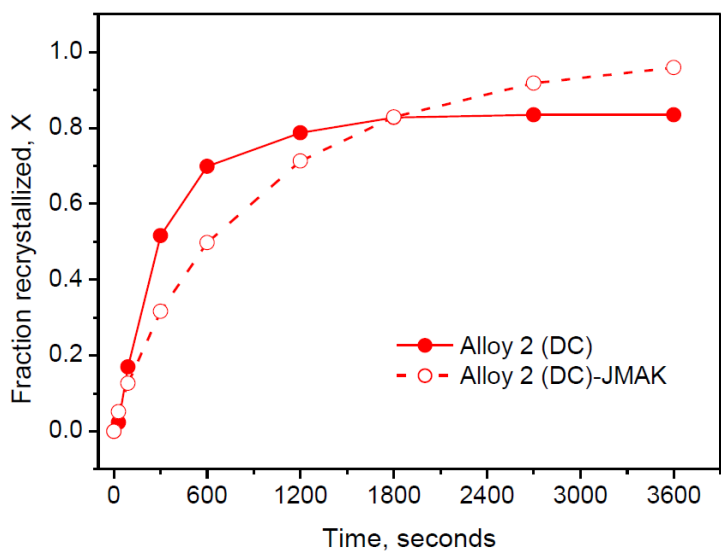

Figure 8. Recrystallization kinetics for the Alloy 2-DC from Micro-hardness data and JMAK analysis.

Recrystallization fraction between two methods, the binary Alloy 1-DC and Alloy 1-HC show the minimum variation. The Zirconium added Alloy 2-HC and Alloy 2-HC show the higher variation because of higher recystallization behavior of these alloys. Prior to hot 
rolling 1 (HC) and Alloy 2 (HC) shows relatively minimum variation because of during homogenizing and hot rolling the alloys already dissolve the second phases as well as the grain corsening of fine precipitates of $\mathrm{Al}_{3} \mathrm{Zr}$.

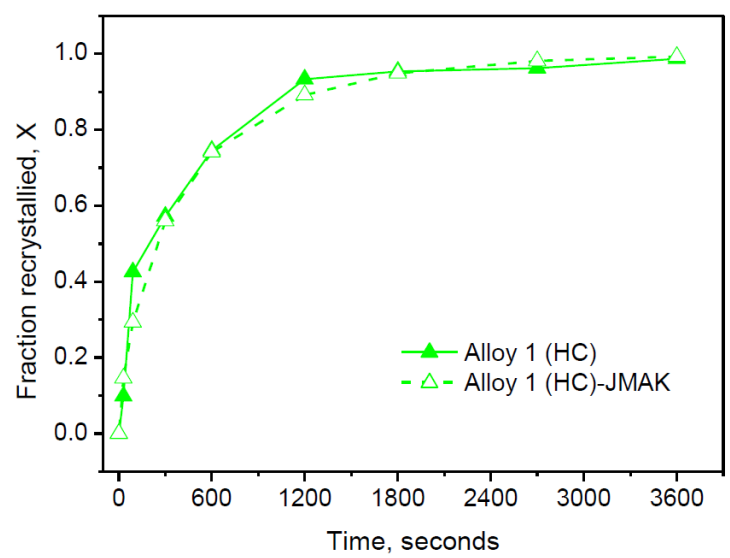

Figure 9. Recrystallization kinetics for the Alloy 1-HC from Micro-hardness data and JMAK analysis.

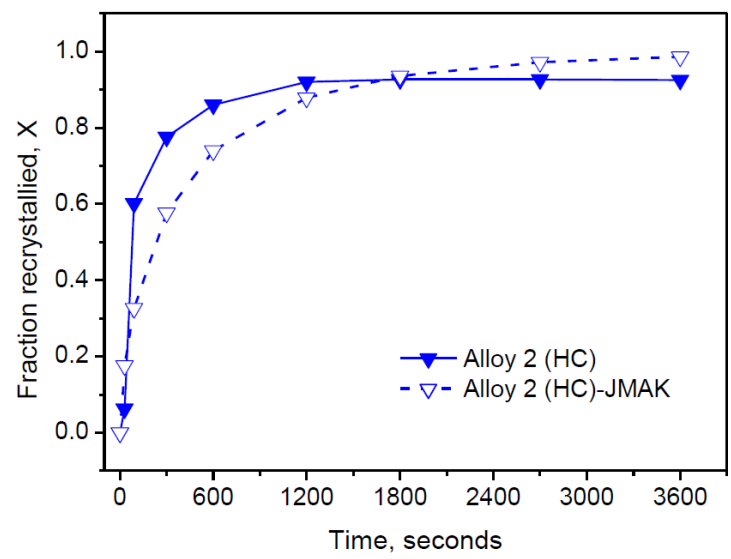

Figure 10. Recrystallization kinetics for the Alloy 2-HC from Micro-hardness data and JMAK analysis.

\section{CONCLUSIONS}

Effects of rolling (Cold rolling and, Hot and cold rolling) on the fractional recrystallization bevaiour of $\mathrm{Al}-\mathrm{Mg}$ alloy and $\mathrm{Zr}$ added $\mathrm{Al}-\mathrm{Mg}$ have been investigated. It is observed from optical micropraphs that during hot and colled rolling, the dendritic structure has been transformed into equiaxed structure while during cold rolling the dendrites are fragmented and alongated in both the alloys. In both the rolling condtions, the $\mathrm{Zr}$ added $\mathrm{Al}-\mathrm{Mg}$ alloys show finer structure as compared to Al-Mg alloy. The fractional recrystallization is found lower in the $\mathrm{Zr}$ containing directly cold rolled Alloy 2-DC sample as compared to that of the directly cold rolled Alloy 1-DC, hot and cold rolled Alloy 1-HC and Alloy 2-HC. $\mathrm{Al}_{3} \mathrm{Zr}$ precipites formed in $\mathrm{Zr}$ containing alloy 2-DC act as recrystallization inhibitor, while in hot and cold rolled condition these precipitates are found to be not effective in alloy 2-HC in inhibitation of recrystallization for the formation of coarse preicpitates.

\section{REFERENCES}

1. Schoenitz M., Dreizin E.L., 2003, "Structure and properties of Al-Mg mechanical alloys", J. Mater. Res., Vol. 18, No. 8, pp. 1827-1836.

2. Wang B., Liu J., Yin M., Xiao Y., Wang X. H., He J. $\mathrm{X}$., 2016, "Comparison of corrosion behavior of Al-Mn and Al-Mg alloys in chloride aqueous solution", Materials and Corrosion, Vol. 67, No. 1, pp. 51-59

3. Huskins E.L., Cao B., Ramesh K.T., 2010, "Strengthening mechanisms in an $\mathrm{Al}-\mathrm{Mg}$ alloy", Materials Science and Engineering: A, Vol. 527, No. 6, pp. 1292-1298

4. Radovic 1., Nikacevic M, 2008, "Microstructure and Properties of Cold Rolled and Annealed Al-Mg Alloys", Scientific Technical Review, Vol. 8, No. 2, pp. 14-19.

5. Kaiser M.S., Datta S., Roychowdhury A., Banerjee M.K., 2008, "Age hardening behaviour of wrought Al-Mg-Sc alloy", Journal of Materials and Manufacturing Processes, Vol. 23, No. 1, pp. 74-81.

6. Noda M., Hirohashi M., Funami K., 2003, "Low temperature superplasticity and Its deformation mechanism in grain refinement of $\mathrm{Al}-\mathrm{Mg}$ alloy by multi-axial alternative forging", Materials Transactions, Vol. 44, No. 11, pp. 2288-2297.

7. Knipling K.E., Dunand D.C., Seidman D.N., 2008, "Precipitation evolution in $\mathrm{Al}-\mathrm{Zr}$ and $\mathrm{Al}-\mathrm{Zr}-\mathrm{Ti}$ alloys during isothermal aging at $375-425^{\circ} \mathrm{C}$, Acta Materialia, Vol. 56, pp. 114-127.

8. Mikhaylovskay A.V., Mochugovskiy A.G., Levchenko V.S., Tabachkova N.Y., Mufalo W., Portnoy V.K., 2018, "Precipitation behavior of $\mathrm{L1}_{2} \mathrm{Al}_{3} \mathrm{Zr}$ phase in $\mathrm{Al}-\mathrm{Mg}-\mathrm{Zr}$ alloy", Materials Characterization, Vol. 139, pp. 30-37.

9. Himuro Y., Koyama K., Bekki Y., 2006, "Precipitation behaviour of zirconium compounds in Zr-bearing Al-Mg-Si alloy", Materials Science Forum, Vol. 519-521, pp. 501-506.

10. Liu W.C., Li J., Yuan, H., Yang Q.X., 2007, “ Effect of recovery on the recrystallization texture of an Al-Mg alloy", Scr. Mater., Vol. 57, pp. 833-836.

11. Attallah M.M., Strangwood M., Davis C.L., 2010, "Influence of the heating rate on the initiation of primary recrystallization in a deformed $\mathrm{Al}-\mathrm{Mg}$ alloy", Scr. Mater., Vol. 63, pp. 371-374.

12. Duckham A., Engler O., Knutsen, R.D., 2002, "Moderation of the recrystallization texture by nucleation at copper-type shear bands in Al-1Mg", Acta Mater, Vol. 50, pp. 2881-2893.

13. Litynska L., Abou-ras D., Kostorz G., Dutkiewicz J., 2006, "TEM and HREM study of $\mathrm{Al}_{3} \mathrm{Zr}$ precipitates in an Al-Mg-Si-Zr alloy", Journal of Microscopy, Vol. 223, No. 3, pp. 182-184. 
14. Cerri E., Leo P., 2005, "Influence of severe plastic deformation on aging of Al-Mg-Si alloys", Metal Science and Engineering A, Vol. 410-411, pp. 226-229.

15. Mrowka-Nowotnik G., Sieniawski J., 2005, "Influence of heat treatment on the microstructure and mechanical properties of 6005 and 6082 aluminium alloys", Journal of Materials Processing Technology, Vol. 162-163, pp. 367-372 .

16. Polmear I.J., 1987, "Role of Trace Elements in Aged Aluminium Alloys", Materials Science Forum, Vol. 13/14, pp. 195-214.

17. Zedalis M.S., Fine M. E., 1986, "Precipitation and ostwald ripening in dilute AI Base-Zr-V alloys", Metallurgical Transactions A, Vol. 17, No. 12, pp. 2187-2198.

18. Knipling K.E., Dunand D.C., Seidman D.N., 2006, "Criteria for developing castable, creep-resistant aluminum-based alloys - A review", Zeitschrift fur Metallkunde, Vol. 97, No. 3, pp. 246-265.

19. Kaiser M.S., 2013, "Precipitation hardening behaviour of directly cold rolled Al-6Mg alloy containing ternary Sc and quaternary Zi/Ti”, International Journal of Mechanical, Industrial Science and Engineering, Vol. 7, No, 4, pp. 174-180.

20. Kaiser M.S., Dutta S., 2014, "Recrystallization kinetics in aluminum piston", Procedia Engineering, Vol. 90, pp. 188-192.

21. Jia Z., Hu G., Forbord B., Solberg J.K., 2007, "Effect of homogenization and alloying elements on recrystallization resistance of Al-Zr-Mn alloys", Materials Science and Engineering A, Vol. 444, pp. 284-290.

22. Croteau J.R., Griffiths S., Rossell M.D, Leinenbach C., Kenel C., Jansen V., Seidman D.N., Dunand D.C., Vo N.Q., 2018, "Microstructure and mechanical properties of Al-Mg-Zr alloys processed by selective laser melting", Acta Materialia, Vol. 153, pp. 35-44.

23. Kaiser M.S., 2018, "Effect of solution treatment on age-hardening behavior of $\mathrm{Al}-12 \mathrm{Si}-1 \mathrm{Mg}-1 \mathrm{Cu}$ piston alloy with trace-Zr addition", Journal of Casting and Materials Engineering, Vol. 2 No. 2, pp. 30-37.

24. Robson, J.D., Pragnell, P.B., 2003, "Modelling $\mathrm{Al}_{3} \mathrm{Zr}$ dispersoid precipitation in multicomponent aluminium alloys." Materials Science and Engineering Vol. A352, pp. 240-250.

25. Kaiser M.S., 2014, "Fractional recrystallization kinetics in directly cold rolled Al-Mg, Al-Mg-Sc and Al-Mg-Sc-Zr alloy" Iranian Journal of Materials

Sciences and Engineering, Vol. 11, No. 4, pp. 80-87.

Journal of Mechanical Engineering, Vol. ME 48, December 2018

Transaction of the Mechanical Engineering Division, The Institution of Engineers, Bangladesh 